\title{
Paseo, sancocho y río. Memorias y olvidos sobre el conflicto armado en Pance, Cali
}

DOI: https://doi.org/10.18046/recs.i28.3268

\author{
Trips, Sancocho and River. Memoirs and Oblivions \\ on the Armed Conflict in Pance, Cali \\ Passeio, sancocho e río. Memórias e esquecimento \\ sobre o conflito armado em Pance, Cali \\ Inés Marcela Medina-Vargas ${ }^{* *}$ \\ Investigadora independiente \\ Yamileth Bolaños-Martínez ${ }^{* * *}$ \\ Luis Fernando Barón ${ }^{* * * *}$ \\ Universidad Icesi (Cali, Colombia)
}

\footnotetext{
* Este texto hace parte de los resultados de los proyectos de investigación "Memorias de empresarios del Pacífico colombiano", realizado por la Universidad Icesi con apoyo del Centro Nacional de Memoria Histórica y la Embajada Suiza, y "Estrategia de manejo socioambiental de la subcuenca del río Pance", financiado por la Universidad Icesi. También es resultado del apoyo de Colciencias (Jóvenes Investigadores de 2015 y 2016) en Cinara, Universidad del Valle, e hizo parte de los procesos de formación de la Maestría en Estudios Sociales y Políticos de la Universidad Icesi. Artículo de investigación recibido el 21.11.18 y aceptado el 06.03.19.

${ }^{* *}$ Profesional en Estudios Políticos y Resolución de Conflictos de la Universidad del Valle. Magíster en Estudios Sociales y Políticos de la Universidad Icesi. Investigadora en ciencias sociales. Correo electrónico: ines.medina@correounivalle. edu.co ORCID: https://orcid.org/oooo-0oo3-3774-2545

*** Psicóloga y magíster en Estudios Sociales y Políticos de la Universidad Icesi. Docente hora cátedra de la misma universidad. Correo electrónico: bmyamileth@gmail.com ORCID: https://orcid.org/oooo-0oo3-0863-6559

**** Doctor en Ciencias de la Información. Profesor e investigador de la Universidad Icesi, con estudios en Comunicación y Antropología. Correo electrónico: lfbaron@icesi.edu.co ORCID: https://orcid.org/oooo-ooo2-4724-8869
} 


\section{Cómo citar/How to cite}

Medina-Vargas, Inés Marcela; Bolaños-Martínez, Yamileth; Barón, Luis Fernando (2019).

Paseo, sancocho y río. Memorias y olvidos sobre el conflicto armado en Pance, Cali.

Revista CS, 28, 47-85. https://doi.org/10.18046/recs.i28.3268 
Resumen

Abstract

Resumo

Este artículo explora memorias de emprendedores de la ribera del río Pance, Cali, Colombia. La travesía por sus recuerdos hace énfasis en dos momentos: las violencias experimentadas durante varias tomas que dejaron, literalmente, a civiles en mitad del fuego cruzado entre organizaciones guerrilleras y la policía; y en los proyectos socioambientales de la región. En el ejercicio de recordar, los participantes de este trabajo tienden a suavizar e invisibilizar experiencias con el conflicto armado, mientras destacan la riqueza natural de su territorio que tiene como eje al río y sus fuentes de agua. Sus narrativas expresan un intento por proteger la sobrevivencia de su comunidad, de sus ecosistemas y del tradicional paseo de los domingos, que representan sus principales fuentes de vida presentes y futuras. Lo anterior, además, ofrece pistas sobre la banalización de experiencias cotidianas del conflicto y la formación de hegemonías de las memorias.

PALABRAS CLAVE:

memoria, conflicto armado, ecosistema, comunidad, Colombia

This article explores the memoirs of entrepreneurs from the Pance River, in Cali, Colombia, by using an ethnographic perspective. The journey through their memories emphasizes two moments: the violence they experienced during three confrontations between guerrilla groups and the police, which left civilians in the crossfire, and the link with the socio-environmental projects in the region. The interviewees reminiscences tend to make invisible their experiences in the armed conflict in order to protect the survival of the community, of their ecosystems, and of the traditional Sunday trips to the river; these are their main sources of living in the present and future. This study offers significant clues on the hegemonies of the memoirs and on how some daily experiences within the armed conflict became culturally trivial.

\section{KEYWORDS:}

Memory, Armed Conflict, Ecosystem, Community, Colombia 
Este artigo explora memórias de empresários das margens do rio Pance, em Cali, na Colômbia. A viagem através de suas lembranças enfatiza dois momentos: a violência vivida durante várias incursões que deixaram, literalmente, civis no fogo cruzado entre as organizações guerrilheiras e a Polícia, e nos projetos socioambientais da região. No exercício de relembrar os participantes deste trabalho, eles tendem a amenizar e tornar invisíveis as experiências com o conflito armado, ao mesmo tempo em que destacam a riqueza natural de seu território que tem como eixo o rio e suas fontes de água. Suas narrativas expressam uma tentativa de proteger a sobrevivência de sua comunidade, seus ecossistemas e os domingos tradicionais, que representam suas principais fontes de vida presente e futura. $\mathrm{O}$ acima também oferece pistas sobre a banalização de experiências cotidianas de conflito e a formação de hegemonias de memórias.

PALAVRAS CHAVE:

memória, conflito armado, ecossistema, comunidade, Colombia 


\section{Introducción}

Oiga, mire, vea,

véngase a Cali para que vea.

Vaya despacito, si ya va prendido,

si va manejando se mete en un lío.

Quédese quietico, ya está amanecido.

$Y$ después de canse váyase pa' Pance.

\section{Orquesta Guayacán ${ }^{1}$}

A partir de 1960, la preocupación por la memoria ${ }^{2}$ adquirió un papel central en Estados Unidos y Europa. Según Huyssen (2002), esta expansión de la memoria se expresó en diferentes hechos, como la restauración historicista de antiguos centros urbanos, el boom del marketing de la nostalgia y la aparición de novelas históricas. La agudización de los debates alrededor del Holocausto representa, para este autor, el detonante del viraje hacia la memoria, y se convierte en un tropos $^{3}$ que, además de hacer visibles otros genocidios en el mundo, demuestra el fracaso del proyecto de la Ilustración, dada la dificultad de vivir en paz con otros en la cultura occidental.

Por su parte, el acto de hacer memoria salta a la escena pública en Latinoamérica, inicialmente para denunciar los actos atroces del terrorismo de Estado en algunas naciones y para permitir brindarle voz a sectores sociales que históricamente habían sido silenciados ${ }^{4}$. De acuerdo con Bustos (2010), la memoria se expandió en ocasiones por encima de la historia, evidenciando cómo ambas se integran en disputas de poder y de contestación social. En Colombia también se ha desatado un boom de estudios y producciones culturales y artísticas sobre la(s) memoria(s) en las

1. Pance es mencionado en la canción Oiga, mire, vea, considerada como un referente musical de la ciudad de Cali, capital de la salsa.

2. Autores, como Huyssen (2002), introducen el término "memoria" en singular, pero en adelante se hará referencia a las memorias en plural, reconociendo que las memorias tienen un carácter de multiplicidad (Calveiro, 2012).

3. Tropos es una figura retórica que consiste en el uso de una palabra con un sentido figurado, según la Real Academia de la Lengua Española. Para Huyssen (20O2), es una metáfora que permite desplazar el significado del Holocausto a otros eventos no relacionados con el contexto histórico del mismo, aunque sí semejantes en la presencia de eventos traumáticos.

4. Así se muestra en el texto sobre Trujillo que hace parte de este mismo número (Garzón, 2019), en donde se hace referencia al boom de la memoria en el continente, particularmente en Argentina, Chile y Uruguay, que es posterior a las dictaduras militares, y está representado por múltiples estudios y producciones políticas y culturales enmarcadas en la búsqueda de justicia para dialogar acerca de lo sucedido, y fomentar valores democráticos en sociedades afectadas por la violencia política (p. e. Allier; Crezel, 2015; Barbuto, 2012; Bickford; Brett; Ríos; Ševčenko, 2007; Fabri, 2013). 
últimas décadas. En el caso de nuestro país, esta situación ha girado alrededor del conflicto político armado, y este boom tiene sus antecedentes en las 15 comisiones (12 nacionales y 3 locales) que han intentado dar cuenta y comprender las violencias y conflictos políticos de Colombia (Pizarro, 2015).

Sin embargo, fue desde comienzos de este siglo que se incrementaron los estudios sobre las memorias, producto, por una parte, de las iniciativas de diálogo y negociación política con grupos armados (como las realizadas por los presidentes Pastrana y Uribe), así como por las significativas respuestas sociales frente a estas iniciativas, expresadas en la gestación de un movimiento socializador de la memoria en el que han participado ONG, asociaciones de víctimas, organizaciones sociales, universidades, entre otras. Además, este movimiento tuvo un significativo incremento de trabajos artísticos, culturales y académicos (Giraldo; Gómez; Cadavid; González, 2011).

Uno de los más importantes hechos relacionados con la trascendencia adquirida por la memoria fue la creación, en 2007, del Grupo de Memoria Histórica sobre el conflicto armado, vinculado a la Comisión Nacional de Reparación y Reconciliación (CNRR). En diciembre de 2011 terminó el trabajo de este grupo que, junto con las movilizaciones mencionadas antes, forzaron la producción y puesta en vigencia de la Ley de Víctimas y Restitución de Tierras, Ley 1448 de 2011 (Congreso de la República de Colombia, 2011), que incluyó la creación del Centro Nacional de Memoria Histórica, $\mathrm{CNMH}$, con la misión de apoyar el proceso de reparación integral y el derecho a la verdad de las víctimas del conflicto armado colombiano y de la sociedad, además de contribuir al deber de memoria del Estado.

El Observatorio del CNMH ha consultado 592 fuentes y 10236 bases de datos y documentos, tanto institucionales como sociales, que evidencian 353531 hechos de violencia. Tan solo entre los años 2014 y 2017, la entidad apoyó 95 iniciativas de memoria histórica sobre el conflicto, publicó 53 investigaciones sobre el esclarecimiento del conflicto armado en Colombia, y respaldó 67 procesos colectivos de memoria histórica y de fortalecimiento de archivo en derechos humanos.

El boom de la memoria en Colombia también se ve reflejado en las últimas versiones de la Comisión Histórica del Conflicto y sus Víctimas, creada en 2015, durante el proceso de paz entre el gobierno del presidente Santos y las Fuerzas Armadas Revolucionarias de Colombia, FARC. De igual forma, se expresa en el diseño e implementación del Sistema de Verdad, Justicia, Reparación y No Repeticións, que se creó con el Acuerdo de Paz de 2016 (Gobierno Nacional de Colombia, 2016), e incluye 
la Jurisdicción Especial para la Paz, la Comisión para el Esclarecimiento y la Verdad, la Unidad para la búsqueda de personas dadas por desaparecidas en el contexto y en razón del conflicto armado, y las medidas de reparación integral. En el ámbito local, este boom se ve expresado en el diseño y gestión de un museo de memorias, y en la existencia de más de cuarenta iniciativas sociales que trabajan en esta línea en Cali.

En este contexto, los trabajos de memoria y las memorias sobre el conflicto armado en Colombia atraviesan por un momento crucial. Por una parte, este boom ha traído indispensables debates y disputas sobre asuntos claves como: quiénes son los agentes de enunciación de las memorias e historias (así como los episodios, tiempos y lugares que estos definen); cuál es el valor de los testimonios que sustentan los relatos e historias personales, colectivas e institucionales; y cuáles son las memorias que se imponen para determinadas colectividades, territorios y coyunturas. Pero, por otra parte, el boom de la memoria, como lo muestra Huyssen (2002), puede conllevar a uno del olvido; esto porque los giros de la memoria también corren el riesgo de producir una sobrecarga de información sobre el pasado, que termina por ahogarlo, por desaparecerlo. Lo anterior puede implicar el silenciamiento, olvido y desconocimiento parcial de voces e historias de carácter regional y local.

Desde las anteriores preguntas y riesgos, este trabajo, antes que sumarse a contribuir a un ruido ensordecedor de memorias en el país y sus regiones, busca ayudar a identificar episodios, agentes y experiencias significativas que han sido invisibilizadas u olvidadas, no solo por la academia, los medios de comunicación o algunos sectores sociales, sino por las mismas comunidades que habitan territorios afectados por el conflicto armado. Así, en este texto se recogen trabajos de investigación iniciados en el año 2015 en el corregimiento de Pance, Cali, que dejan observar las articulaciones de las memorias del conflicto con la vida cotidiana, las identidades y los olvidos, y sus relaciones con los ríos, los bosques y la fauna de la zona, así como con algunas tradiciones locales.

Entre varios testimonios, este trabajo se centra en las remembranzas de Evangelina y Alba -madre e hija-, y Lucio $^{6}$-vecino del lugar-, quienes han dedicado sus vidas al tradicional negocio del sancocho de gallina a las orillas del río Pance. Sus relatos ayudan a dar visibilidad y a analizar sus vivencias y recuerdos en momentos en los que se escaló el conflicto armado en el país y la región, dando lugar a reflexiones sobre los usos y roles que cumplen sus memorias para el territorio y sus propias vidas.

En lo que sigue, el artículo inicia con una reflexión que muestra las relaciones entre las memorias (recuerdos y olvidos), las narrativas y la identidad, para luego

6. Los nombres y algunos detalles de sus relatos han sido cambiados para proteger su identidad. Sin embargo, se ha tratado de ser lo más preciso, responsable y justo posible con las experiencias vividas, rememoradas y relatadas por ellos. 
presentar la metodología empleada y herramientas de indagación desarrolladas en las dos investigaciones que soportan este trabajo. Esta reflexión está seguida por una explicación del uso de la información recolectada y una ubicación de las características espaciales de Pance. Después, se exponen las memorias trabajadas con los participantes, que son presentadas a manera de tramas ${ }^{7}$, alrededor de las tomas guerrilleras y de los trabajos ambientales en la zona. Finalmente, se propone una discusión y unas conclusiones que se preguntan por la banalización de las violencias del conflicto armado y por hegemonías de las memorias que excluyen los recuerdos de violencias cotidianas producidas en territorios particulares.

\section{Conceptualización: la(s) memoria(s)}

En este estudio se reconoce que la(s) memoria(s), además de unas condiciones físicas y materiales (de carácter neurológico ${ }^{8}$, y de ciertas capacidades individuales, funciona y tiene significación y sentido en ámbitos intersubjetivos, colectivos e institucionales, que no solo requieren de la identificación de un yo, de un nosotros y de unos otros, sino que hacen parte de complejas disputas por representaciones y narrativas sociales que tienen implicaciones en el ejercicio de poderes económicos, políticos, culturales y sociales (Barón, 2018; Calveiro, 2012; Carrillo-Mora, 2010; Kirwan; Ashby; Nash, 2014; Ricoeur, 2004).

Así, la reflexión conceptual que guía este trabajo articula tres asuntos nodales para la recomposición del pasado: memorias (recuerdos-olvidos), narración (individual-colectiva) e Identidades. Estos ejes son abordados de forma articulada, entendiendo que los ejercicios de memoria implican tanto acciones individuales como colectivas que contribuyen a la construcción de identidades que se pueden rastrear por medio de las narraciones. En lo que sigue, se ampliarán estos ejes teóricos.

Desde la perspectiva de Todorov, olvido y memoria no se oponen. El olvido es parte constitutiva del proceso de memoria, y permite sanar y liberar. Los recuerdos que permanecen posibilitan la vida individual y colectiva, y los ejercicios de memoria que apelan a los principios de justicia permiten la formación de lo que este autor denomina "memorias ejemplares" (Todorov, 200o). Así, los ejercicios responsables de la memoria imponen límites prudenciales a los reclamos sobre el pasado, para

7. Desde Ricoeur (2004), este término se refiere a relatos que organizan recuerdos para lograr unos textos inteligibles. Este concepto es ampliado y explicado más adelante.

8. Estudios de la neurociencia sostienen que la memoria es una habilidad cognitiva de los seres humanos que sucede en el hipocampo del cerebro, y que los actos de memoria, así como los de la imaginación, se producen en los mismos lugares del cerebro. Recordar e imaginar son actos relacionales. 
no hacer pesar sobre la sociedad todos los conflictos y las culpas pasadas, y permitir la construcción solidaria del futuro. En este sentido, no se trata simplemente del ejercicio de recordar y de olvidar, sino que se olvida con unos propósitos.

Otros autores, como Huyssen (2002), Ricoeur (2004), Nietzsche (2006) y Rieff (2012), le dan un sentido de humanidad y justicia al olvido, porque enmarcan el no recordarlo todo en pro de la vida y el bienestar. Para estos autores, también se hace necesario reconstruir el pasado para comprender el presente y la historia con miras al futuro. Por lo tanto, no es solo el olvidar o recordar, sino también por qué (pasado-presente) y para qué (futuro). Recordar y olvidar es lo que permite otorgarle usos a la memoria. En palabras de Huyssen (2002), "el porvenir no habrá de juzgarnos por olvidar, sino por recordarlo todo y, aun así, no actuar en concordancia con esos recuerdos" (166). Podríamos decir, entonces, que la selección de lo que olvidamos o recordamos debería estar orientada por un criterio de justicia, y es ahí donde las memorias son benevolentes y, en cierto modo, portadoras de libertad.

Aunque los olvidos en ocasiones responden a este criterio de justicia, hay momentos en los que se olvida sin criterio alguno y se almacenan sucesos en la memoria que responden más a lo que se difunde en los medios masivos de comunicación que a un ejercicio juicioso de reflexión.

Cada vez más, los críticos acusan a la cultura de la memoria contemporánea de amnesia, de anestesia u obnubilación. Le reprochan su falta de capacidad para recordar y lamentan la falta de conciencia histórica. La acusación de amnesia viene envuelta invariablemente de una crítica a los medios, cuando son precisamente esos medios (...) los que día a día nos dan acceso a cada vez más memoria. ¿Qué sucedería si ambas observaciones fueran ciertas, si el boom de la memoria fuera inevitablemente acompañado por un boom del olvido? (Huyssen, 2002: 22).

Olvidar es problemático cuando no responde a un proceso de reflexión y, por tanto, no se encuentra de la mano con el principio de justicia. Los medios de comunicación saturan a la memoria con la gran cantidad de información que ofrecen. Además, algunas veces lo que hay detrás de este boom de información son propósitos que responden a unas dimensiones políticas y que son funcionales a las relaciones de poder vigentes (Calveiro, 2012).

Para Calveiro (2012), no es posible hablar de una memoria, sino de la construcción de memorias, en plural, porque sus interpretaciones de lo vivido son desplegadas en el actuar presente, de ahí su carácter político. En esta perspectiva, se entiende que las memorias hacen parte de sistemas de representación que se crean y recrean en redes de interacciones comunicativas (narrativas) que están inmersas en luchas 
simbólicas donde se configuran hegemonías y regímenes de representación', que incluyen prácticas de resistencia y contradicción a regímenes móviles, no estáticos, influidos por tiempos, espacios, agentes y materialidades particulares. Toda esta composición de las memorias configura identidades entre sus representantes.

Por consiguiente, las memorias no pueden entenderse únicamente como un constructo individual, sino que están "hechas de referentes individuales y de hábitos comunitarios, ligadas a tradiciones locales, regionales, religiosas, profesionales y consuetudinarias" (Nora, 2008: 191). De la mano de Nora, es posible entender que la narración contribuye a las relaciones entre las memorias individuales y colectivas, y a las identidades individuales y colectivas. Por lo tanto, la transmisión de la memoria se produce no solo a nivel individual por medio del recuerdo, sino que también se transmite a partir de lo que conocemos como narración oral, un tipo de transmisión de la memoria que resulta de difícil conservación. Además, la memoria se puede transmitir mediante lugares de memorias, como los museos, los archivos, los aniversarios o las celebraciones, una forma de transmisión que permite un grado más alto de preservación de los recuerdos. Desde la perspectiva de Nora, estas dos maneras de transmisión son empleadas con el fin de no olvidar, aportando a las identidades colectivas y, particularmente, a las nacionales.

Por lo anterior, hacer memoria es un proceso humano fundamental para la constitución del yo, que requiere de interacciones materiales y de la acción simbólica. Como se plantea en párrafos anteriores, la formación de las memorias y la dotación de sentido se dan en relación con otros; es decir, se trasciende una mirada individualista y aislada del ser humano, y se plantea que quien recuerda lo hace situado en relación con otras personas y colectivos (Lambek; Antze, 1996). Desde Bruner (2002), la construcción del yo es también una creación narrativa que tiene propósitos, y se produce por medio de una relación dialéctica entre nuestra creencia de poder elegir autónomamente frente a nuestra cotidianidad y la limitación de esta autonomía proveniente de la cultura y de las expectativas derivadas de nuestras relaciones con otros. En el hacer memoria, entonces, no solo hay una cierta convicción de que se tiene voluntad propia, sino una alteridad que nos pone en relación con los demás.

\section{Metodología}

La metodología de este estudio fue primordialmente cualitativa, es decir, indagó acerca de los fenómenos de acuerdo con los significados que tenían para las personas implicadas. Con este marco, se desarrolló un ejercicio etnográfico que englobó un con- 
junto de técnicas, tales como: la observación participante, las entrevistas informales o formalmente estructuradas, el uso de encuestas y la revisión de archivo, con el fin de "estar ahí" con la comunidad para contrastar lo que dice o se dice de las personas, y poder observar lo que ellas hacen y sus relaciones con sus relatos (Stoller, 2007).

Esta investigación recogió, en primer lugar, insumos de la participación en la Maestría en Estudios Sociales y Políticos, entre 2017 y 2018; además, se contó con la información recolectada en el programa joven investigador de Colciencias por dos años consecutivos (2015 y 2016) en Cinara, Universidad del Valle, tiempo en que también se hizo parte del proyecto "Estrategia de Manejo Socio-ambiental de las zonas media y baja de la subcuenca del río Pance" "10 (Mesa ambiental corregimiento de Pance, 2016), desarrollado por la Universidad Icesi durante los mismos años, con el propósito de conocer las estrategias de la comunidad para proteger su territorio. Durante este primer período, se trabajó con miembros de la comunidad de dos veredas de la parte media baja y media alta de Pance, a través de observaciones participantes, y talleres con niños y niñas del sector, que incluyeron cartografías sociales y entrevistas semiestructuradas con nueve líderes comunitarios, diez miembros de las familias asentadas en la zona y siete comerciantes.

Lo anterior, enfocado en entender sus relaciones con el ecosistema y sus percepciones del mismo. Durante este trabajo de campo emergieron con fuerza las relaciones entre el territorio, sus comunidades y el conflicto armado. Por tanto, se realizó un nuevo trabajo de campo durante siete meses, al que se invitó a líderes comunitarios para que desarrollaran ejercicios de memoria alrededor de experiencias significativas relacionadas con el conflicto armado, mediante entrevistas semiestructuradas, observaciones participantes y conversaciones informales. Todo lo anterior, en el marco del proyecto de investigación sobre "Memorias de Emprendedores y Empresarios del Pacífico Colombiano", desarrollado entre la Universidad Icesi y el Centro Nacional de Memoria Histórica, con el apoyo de la embajada suiza. En el proceso, se decidió concentrar el trabajo de memorias con tres líderes (Alba, Evangelina y Lucio), teniendo en cuenta los siguientes criterios: 1) ser emprendedores o empresarios de la zona; 2) haber vivido y permanecido en Pance durante el conflicto armado; 3) tener vínculos fuertes con la comunidad y el lugar; y 4) su interés por participar en la investigación y hacer un ejercicio de rememoración.

Los emprendedores y empresarios (EE) se caracterizan por ser agentes que hacen parte de redes, campos y actividades económicas muy diversas, con recursos y capitales propios o ajenos, cuyo fin es obtener o incrementar esos recursos y capitales. Incluyen desde acciones cooperativas y asociativas, pasando por empresas

10. Este proyecto se construyó con la comunidad de Pance durante 18 meses. Ver http://www.panceambiental.org 
familiares, hasta conglomerados y corporaciones internacionales y globales (Barón, 2018). Varela y Bedoya (2006) establecen una distinción entre emprendedores y empresarios, otorgando a los primeros la capacidad de anticiparse a los acontecimientos y, más importante, ser personas que saben y conocen los ámbitos en los que se desenvuelven. Los segundos se caracterizan por el desarrollo de nuevas empresas, valores, riquezas y empleos.

Con las fuentes consultadas, se realizaron análisis cruzados a partir de los cuales se elaboraron textos que presentan unas tramas, en la perspectiva de Ricoeur (2004). Es decir, unos relatos en los que los investigadores han organizado una serie de recuerdos para lograr unos todos inteligibles, bajo el entendido de que la vida y la realidad no se presentan de manera ordenada y causal, y que las vivencias y remembranzas de las personas que han experimentado el conflicto armado difieren en tiempos, espacios y acontecimientos. Para Ricoeur (2004), estas tramas contribuyen a la creación de textos mediadores que ayudan a las relaciones entre los seres humanos (comunicabilidad), a las relaciones entre los seres humanos y sus entornos (referencialidad) y a las relaciones entre los seres humanos consigo mismos (identidad).

De igual forma, para el proceder metodológico se tuvo en cuenta el concepto de "trayectoria", que es definido por Bourdieu (1989) como "la serie de posiciones sucesivamente ocupadas por un mismo agente (o un mismo grupo) en un espacio en devenir y sometido a incesantes transformaciones" (31). Este concepto se retomó para comprender, desde un abordaje crítico, los relatos expresados por las personas entrevistadas, como construcciones que toman en consideración diferentes posiciones asumidas por los sujetos en relación con otros acontecimientos sociales. Por lo tanto, al asumir el término trayectoria, se toma distancia de entendimientos estáticos de las historias de vida que, de acuerdo a Bourdieu, pueden resultar absurdas cuando solo se remiten a un sujeto, cuya constancia puede ser puesta en duda. Las trayectorias se reconstruyeron mediante entrevistas en profundidad, considerando esta como una técnica diseñada para producir imágenes profundas y complejas de los recuerdos de los participantes. Siguiendo a Spradley (1979), las entrevistas en profundidad buscan establecer una relación de humano a humano con los participantes y comprender, en lugar de explicar.

El desarrollo de todas las prácticas y herramientas de la investigación contó con el compromiso de absoluta confidencialidad y garantía de privacidad y anonimato por parte de las entidades participantes y del equipo de investigación, amparados por el secreto profesional. Además, se adoptaron procedimientos y rutinas en el tratamiento de la información recolectada, la cual fue tratada con extremo cuidado y seguridad, incluyendo las condiciones de recolección de información, grabación y 
registro de testimonios, manejo y archivo de información, así como la divulgación y presentación de apartes de la misma.

En el ejercicio de memorias realizado, los participantes iniciaron hablando sobre el conflicto armado, principalmente sobre las tomas guerrilleras en Pance. Posteriormente, sus relatos migraron hacia el presente de ellos como emprendedores del sancocho en Pance y el futuro de su actividad turística, intrínsecamente relacionada con la preservación del río. Por lo anterior, se decidió conservar este orden en la presentación de sus memorias, como se verá más adelante.

Todas las fuentes primarias y secundarias fueron trabajadas con un método de análisis de contenido (Nastase; Koeszegi; Szpakowicz, 2007) que incluyó la organización del material textual en unidades de análisis, la clasificación y diseño de categorías correspondientes con las preguntas de investigación a través de un proceso interactivo de análisis y la posterior producción de unos relatos al estilo de lo que el filósofo y antropólogo Paul Ricoeur (2004) entiende por tramas.

\section{El lugar: Pance}

Al salir de Santiago de Cali con rumbo al sur, se encuentran los imponentes farallones, un conjunto de montañas rocosas y boscosas de la Cordillera Occidental de los Andes colombianos, donde nace el río Pance, a una altura aproximada de 4000 $\mathrm{msnm}$. Esta es el área protegida más grande en el Valle del Cauca, un reservorio de diversidad de especies únicas y en peligro de extinción en Colombia y en el mundo. Allí, el río no solo se convierte en guía del visitante hasta la zona, sino que es también muestra anticipada de la riqueza hidrográfica de la región. Pance significa, en lengua Paez, ciudad de las aguas ${ }^{11}$, nombre del corregimiento más extenso en el área rural de Cali, con 10508 ha y una población de 2359 personas. Esta zona se caracteriza por su gran capacidad de producir aguas puras y cristalinas $^{12}$, que fluyen en diferentes quebradas que desembocan en los ríos Pance, Jamundí, Lili y Meléndez ${ }^{13}$.

La subcuenca presenta alta diversidad vegetal y de climas, desde bosque húmedo tropical (200-1200 msnm), bosque subandino húmedo (1200-200o msnm),

11. La lengua paez era hablada por la comunidad indígena de los Lilíes, que habitaba en el territorio de Pance (Buscan la declaratoria de todo Pance, como una zona de reserva natural, 2017)

12. De los siete ríos del municipio, solo el Pance conserva una buena calidad en sus aguas, desde la parte alta del corregimiento hasta su desembocadura en el río Jamundí (Departamento Administrativo de Gestión del Medio Ambiente (DAGMA), 2012).

13. De acuerdo con el Plan de Ordenamiento Territorial de Cali (Concejo de Santiago de Cali, 2014), en esta zona se ubica el $26 \%$ del total de nacimientos de agua de Cali, la mayor densidad para la ciudad. 
FIGURA 1 $\mid$ Muestra de dibujos y cartografía de los participantes sobre Pance

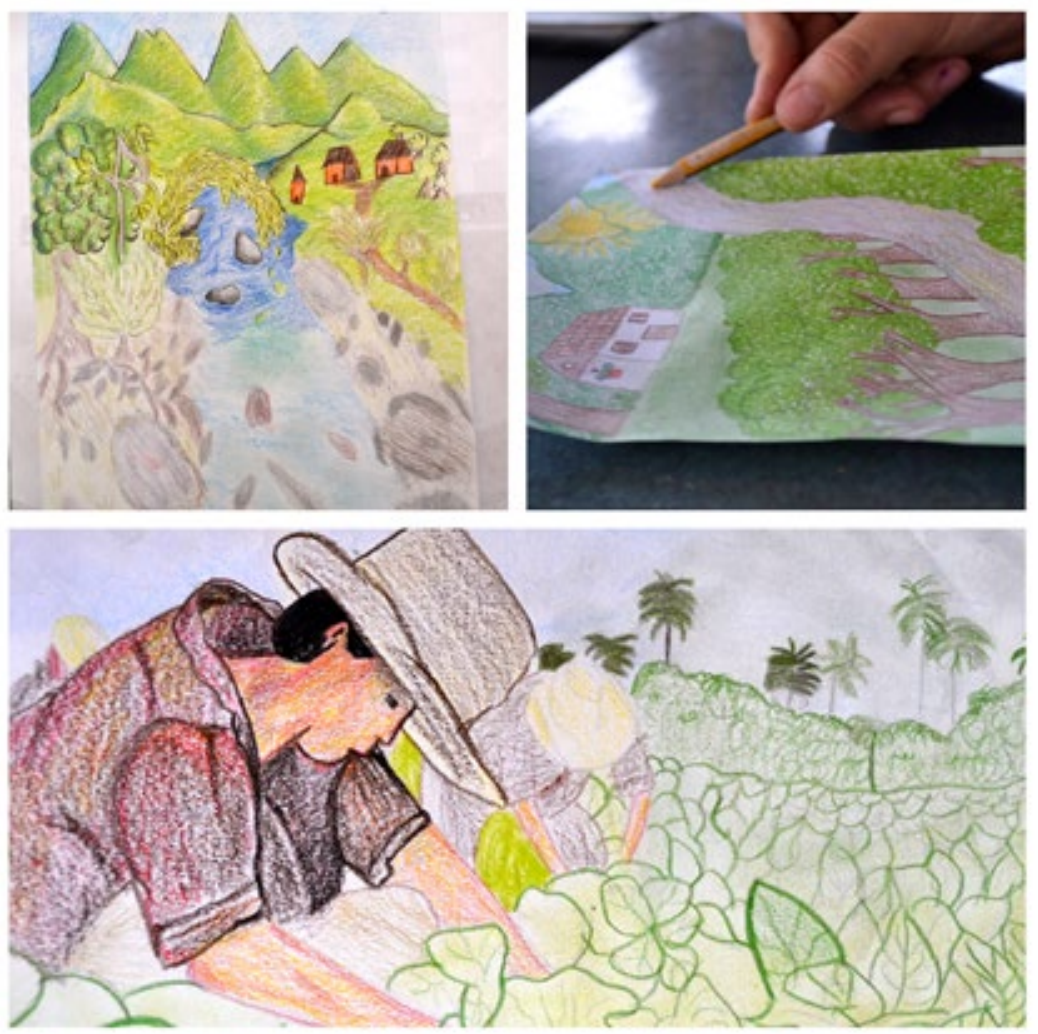

Fuente: dibujos desarrollados en el marco de un taller de ilustración durante el proceso de investigación de la EMSAP

bosque altoandino húmedo (2000-3500 $\mathrm{msnm}$ ) y páramo (superior a $3500 \mathrm{msnm}$ ). $\mathrm{Su}$ diversidad es reconocida por los habitantes del corregimiento, tal y como se puede observar en la Figura 1. Una parte del territorio está integrado por la zona de reserva forestal y por el Parque Nacional Natural Farallones de Cali (PNNFC), que tiene como objetivo principal garantizar la protección de los suelos y la regulación de los caudales, para que afecte positivamente la climatología e hidrología del sur de Cali (Parques Nacionales Naturales de Colombia, 2018; Pizano; García, 2014).

Cada zona del corregimiento tiene algo que aportar como ecosistema a aquellos que lo visitan: la parte baja es perfecta en días calurosos para gozar del río y las actividades que conllevan el tradicional "paseo de olla”, pero también en la parte alta se realizan actividades relacionadas con el senderismo ecológico, avistamiento de 
aves, así como otras actividades orientadas más a la educación ambiental y el deporte (escalar los picos de los farallones, ciclo-montañismo, entre los más destacados).

De acuerdo con Domínguez (2011), el pie de monte de los farallones y sus montañas eran habitados por los pances, perollegaron, también, negros cimarrones que huían de las propiedades señoriales, y ambos vivían principalmente de la explotación artesanal de oro. Para este autor, fueron estos últimos los que vendieron sus propiedades a migrantes desde inicios del siglo XX y, posteriormente, se dedicarían a actividades agrícolas y mineras. Según Pérez (2017), el corregimiento de Pance se conformó en la primera mitad del siglo XX, con la llegada de grupos familiares provenientes mayoritariamente del norte del Cauca, quienes se dedicaron a trabajar en cultivos de pancoger, la minería de carbón y la explotación forestal. Con el tiempo, las actividades económicas se transformaron, producto de la declaración del corregimiento como zona de amortiguamiento PNNFC, creado en 1968.

Es a mediados del siglo XX cuando también toma fuerza el "paseo al río" en la ciudad, producto de un flujo lento y constante de sus habitantes que visitaban ríos como el Aguacatal, el Cañaveralejo, el Lili y el mismo Pance (Vásquez, 2001). El paseo a este último se empezó a convertir en una tradición representativa en el imaginario colectivo por razones que incluyen la calidad de su ecosistema (Salazar, 2018).

Entre los años sesenta y ochenta -afirma Domínguez (2011)- en la zona hubo un desarrollo significativo de la caficultura, apoyado por la Federación Nacional de Cafeteros. Sin embargo, según el autor, la baja de los precios internacionales, unida a la plaga de la roya y el auge del narcotráfico en Cali, condujeron al quiebre y empobrecimiento de campesinos, que terminaron vendiendo sus parcelas, principalmente, a narcotraficantes que las convirtieron en fincas de recreo. Otras se convirtieron en lugares de descanso y recreación para bañistas y turistas. Algunos campesinos se volvieron jornaleros o vigilantes, otros comerciantes y otros se integraron a la construcción. Los más jóvenes, con estudios de primaria y bachillerato, empezaron a emplearse en la zona urbana o a estudiar, convirtiendo la zona en pequeños poblados-dormitorio. De acuerdo con Pérez (2017), las actividades económicas pasaron de priorizar el sector primario de la economía a centrarse en el sector terciario, con el turismo, aspecto que redundó en un cambio de valores de la vida y la producción campesina a unos más cercanos a la vida urbana.

\section{Los agentes: Evangelina, Lucio y Alba}

Evangelina llegó a Pance a mediados de los años setenta. Venía de una zona rural del sur de Colombia, huyendo de la pobreza y en busca de educación. A los 12 años llegó a Cali a trabajar en el servicio doméstico, y a los 15, cuando trabajaba en una panadería, 
se conoció con Pedro, quien hacía parte de una familia con varios negocios en Cali. De allí provino el dinero que él invirtió junto a su hermano para comprar un terreno en esta zona, donde pensaban dedicarse a la vida del campo. Dos años después, ella se convirtió en su compañera, "porque no estaba de acuerdo con el matrimonio".

Cuando Pedro llegó a lo que hoy se conoce como parte media del corregimiento de Pance, la actividad más importante de la zona era la explotación del carbón, como lo cuentan habitantes del lugar. Pedro se dedicó a la agricultura y, con su familia, creó un negocio, como el de una de sus vecinas que compró un terreno cerca del río, para alimentar a las familias que venían los domingos a visitar a los mineros y a bañarse en el río. Allí -dice Evangelina- empezó esta práctica que luego se convertiría en tradición popular. Alba nació diez años después, cuando esta iniciativa ya se había convertido en un estadero (restaurante) y empezaba a florecer el turismo en la zona.

Contaba mi papá que se venían a bañar al río y encargaban su sancocho. Él iba a la finca, sacaba el plátano, la yuca, pelaban la gallina y le preparaban el sancocho, eso era lo que se ofrecía como servicio. Y el baño en el charco o el río, pues, que toda la vida existió (Alba, comunicación personal).

Durante los años setenta, Cali y el departamento del Valle del Cauca vivían rápidos procesos de urbanización y de crecimiento industrial, impulsados principalmente por el desarrollo de los ingenios azucareros. También se vivían los coletazos de las migraciones generadas en los municipios de montaña del sur del Eje Cafetero y del norte del Valle, propiciadas por las violencias partidistas y la creación y expansión de los primeros grupos guerrilleros durante la década de 1960. De acuerdo con el Grupo de Memoria Histórica (2013), esta época corresponde con el primero de cuatro períodos del conflicto armado en Colombia (1958-1982), caracterizado por la transformación de la violencia entre los partidos conservador y liberal, hacia la violencia subversiva con la expansión de los grupos guerrilleros.

En 1974 surgió el M-19, integrado por estudiantes universitarios, varios de ellos de élites intelectuales y sociales de Cali, con una perspectiva de guerrilla urbana (Luna, 2006: 175). Sin embargo, en esta década otros grupos guerrilleros como el EPL y ELN se replegaron, mientras las FARC se expandían hacia el Magdalena medio y el Urabá, influenciadas por el triunfo de la revolución sandinista (Grupo de Memoria Histórica, 2013).

Los recuerdos de Lucio también coinciden con este tiempo. Sus padres provenían del Cauca, de familias “andariegas y rebuscadoras" que trabajaron en la explotación de madera, en ganadería y que llegaron a Pance en medio de la "bonanza de las minas de Cementos del Valle”. Él no recuerda bien cómo se conocieron sus papás, pero sabe que vinieron a este lugar en busca de mejores condiciones de vida y allí 
crearon negocios de tiendas y comidas típicas. Lucio creció en esta zona y logró cursar hasta el bachillerato, a pesar de la inexistencia de instituciones de secundaria en el corregimiento. Sin embargo, desde muy joven empezó a trabajar rozando y haciendo huertas en varias fincas del lugar. También trabajó en construcción, en reparación de electrodomésticos y en culinaria, que sería la base del negocio que tiene en la actualidad.

Desde mediados de los setenta hasta la actualidad, las vidas de Evangelina, Alba y Lucio se han cruzado en Pance. Allí, ellas son hoy dueñas y administradoras de un restaurante (estadero), y se definen a sí mismas como emprendedoras y "cuidadoras de la tradición del sancocho de gallina" a orillas del río. Lucio, por su parte, tiene un local de comidas típicas y se nombra a sí mismo como un pequeño empresario dedicado a la venta de comidas representativas del lugar. Lucio y Alba, cada uno por su parte, han participado de varias iniciativas de preservación del río, como campañas de limpieza, trabajos de formación ambiental en escuelas y colegios, recorridos ecológicos con la comunidad, y marchas por la conservación del ecosistema de su región.

En su texto sobre Pance, Domínguez (2011) hace referencia a la discusión de proyectos medioambientales en la zona desde esta época que, según el autor, no prosperaron por falta de apoyo estatal y por "intrigas intestinas" entre familias con liderazgo en la región que, al parecer, estaban relacionadas con antiguas prácticas del clientelismo bipartidista. Estos proyectos incluían propuestas de reciclaje comunitario con componentes de educación ambiental; un sistema de tratamiento de aguas residuales y excretas, para no contaminar el río Pance; la creación de casas-hoteles para turistas; y la creación de un "retén turístico" para invertir en obras que mejoraran la atención para los visitantes. "Todas estas iniciativas estaban enmarcadas dentro de un gran proyecto de creación y explotación de un Ecoparque, que brindara garantías de explotación económica del turismo sin dañar el medio ambiente y que redujera el impacto de la crisis provocada por el desempleo" (Domínguez, 2011:128).

\section{Las tomas}

Los veía con botas y ruana. Venían a pedir cosas y mi papá me entraba... como mi papá era una de las únicas personas que tenía carro, cuando había alguien enfermo él lo ayudaba. Él se quedaba y se trasnochaba por allá y esperaba que las personas las atendiera el médico. Él ayudaba en lo que podía, porque aquí se veía mucha necesidad (Alba, comunicación personal). 
Durante los años ochenta, los movimientos sociales en Colombia experimentaban una politización hacia las armas, en medio de una expansión de los grupos guerrilleros, con un debilitamiento y persecución de las expresiones sociales, en medio de una significativa polarización social (Grupo de Memoria Histórica, 2013; Luna, 2006). En 1984, el ELN creó el Frente Suroccidental, que más tarde sería reforzado con la creación del Frente Luis Carlos Cárdenas del Norte del Valle. Y, en 1986, este grupo adoptó el modelo de guerra popular prolongada, haciendo énfasis en el trabajo político, y en la construcción de instituciones e instrumentos de poder popular (Echandía, 2013).

En Cali y el Valle del Cauca, las violencias de los años ochenta estuvieron asociadas, principalmente, a la frustración política de estudiantes, y de pobres y marginados. Además, surgió el fenómeno del narcotráfico y se intensificaron las acciones del M-19. Adicionalmente, aparecieron en escena grupos de sicarios y del MAS (muerte a secuestradores). Sin embargo, la mayor manifestación de la violencia en este tiempo estaba asociada a las denominadas "limpiezas sociales", campañas de asesinatos realizadas o apoyadas por grupos de élite y de poder local, en contra de personas y grupos, en razón de sus actividades y situación económica, condición sexual, de género y raza, o sus creencias políticas, entre las más comunes. Estas acciones, según Camacho y Guzmán (1987), fueron subestimadas socialmente y no fueron reportadas por la prensa escrita.

En esta década, Pance experimentó una bonanza económica producida por la afluencia de turistas y la proliferación de servicios turísticos variados, que correspondían con un rápido crecimiento del sector económico de servicios en Cali, generado por el impacto del narcotráfico en la desindustrialización de la región (Guzmán; Rodríguez; Muñoz, 2018). Sin embargo, desde finales de los ochenta empezó un período de repliegue económico en Pance, y aumentaron el desempleo y la delincuencia por el fracaso de varias propuestas turísticas que habían surgido previamente y que no contaron con apoyo estatal.

A este panorama se le sumó la irrupción de grupos armados, como el Frente 30 de las FARC, que controlaron, desde 1991 hasta el año 2000, la parte alta de la subcuenca del río Pance. En su estudio sobre la expansión y control territorial de las FARC-EP en Pance, Domínguez (2011) muestra cómo esta organización logró asentarse en esta zona desde antes de los años noventa, siguiendo parámetros y políticas nacionales de esta guerrilla que incluían: "control inicial a la delincuencia común, arbitraje en los conflictos familiares y comunitarios y reclutamiento de combatientes especialmente entre la población joven" (130). 
En este sentido, pobladores de Pance narran que todo empezó a cambiar en la zona cuando llegaron los grupos guerrilleros. Varios de ellos relatan que primero se escuchaba hablar de las FARC y luego del ELN:

Las FARC y el ELN se reunían en la parte alta del corregimiento, se dice que el ELN no permanecía en el territorio ni operaban en él, pero cuando ellos pasaban se reunían con las FARC, una vez se llegaron a ver como unos 200 del ELN (...). Cuando llegó la guerrilla, aquí ni había presencia estatal, las fuerzas militares pasaban momentáneamente, estaban aquí de vez en cuando y no sé, eso para mí que la zona la ocupaban ciertos grupos (Policía jubilado, comunicación personal).

Uno de ellos comentó que varios de sus amigos de crianza, con los que jugaba fútbol, resultaron involucrados con la guerrilla. A la policía y ejército no iban porque "el personal se está rotando, y uno sabe que ellos son policías y ellos están con uno y charlan, pero es un contacto pasajero, pues, porque los están renovando, no es una amistad permanente" (habitante del sector). Para este poblador, los mayores impactos de esa presencia fueron los hostigamientos, los asesinatos de algunos de sus amigos y la desconfianza en personas y familias que hacían parte de sus amistades “(...) los que eran de la zona, trataban de involucrarlo a uno, pero nosotros no les copiamos".

Doña Evangelina recuerda que una de las primeras tomas fue en 1986, y miembros del ELN pintaron sus siglas en las paredes de las casas. El objetivo era acabar con la estación de policía más cercana y usaban a la población civil como escudo contra los ataques de la policía. Este primer ataque duró, aproximadamente, dos horas. Alba no tenía más de 5 años.

\footnotetext{
Nos encerramos. Yo tenía una máquina de coser Singer. Ella se me metió debajo de la máquina asustada, pues no lloraba porque estaba conmigo (...), ahí en esa pared de allá hicieron un boquete que pasó a la de la cocina y nosotros estábamos allá en el sótano. Por encima del techo, las balas se encontraban así. La guerrilla estaba en el mirador y la policía acá, eso era pum, pum (Evangelina, comunicación personal).
}

Hacia el río estaban los policías y del otro lado, cruzando la carretera, estaban los guerrilleros. En la mitad quedaban las casas y los negocios del sector, que formaban una barrera entre ambos bandos, y en su interior se escondían las personas que solo esperaban que todo cesara. En palabras de Evangelina: "eso era como el fin del mundo". El enfrentamiento duró una hora y media, y para Evangelina lo más preocupante en esos momentos de angustia era el bienestar de Alba, a quien no desprotegió en ningún momento. Recuerda que sus oídos le dolían porque el sonido 
de los disparos era ensordecedor y algunos gritaban: " $i L a$ guerrilla, la guerrilla...! Estábamos muy asustadas y no comprendíamos las razones del enfrentamiento, ni de sus responsables".

Doña Evangelina narra que, tras el atentado, tuvieron que sobrevivir de lo que producía la finca y de las gallinas destinadas para los turistas. "La gente come miedo", y continúa: "Durante un mes esto se puso pesado, no se vendía nada, uno tenía que gastar los ahorros que guardaba para poder sobrevivir porque la gente no subía hasta por un mes".

Otro poblador y líder comunitario de la zona media alta de Pance concuerda con la fecha de ocurrencia de los hechos narrada por Evangelina. Él recuerda una primera toma en el año de 1986. En este año, a un habitante y trabajador de la zona lo enviaron cargado con cilindros de gas, con el fin de obstruir la carretera de acceso de la ciudad hacia el corregimiento, según este poblador.

No obstante, la revisión documental y de prensa muestra un registro de siete incursiones guerrilleras en la zona de Pance, que involucran a la zona media alta, entre 1991 y $2003^{14}$. Los habitantes de estas veredas no se ponen de acuerdo con el número de tomas y hostigamientos en el sector. Algunos hablan de cinco, la mayoría dice que solo hubo dos. Por ejemplo, Alba afirma que fueron tres. Ella piensa que las personas solo cuentan como tomas aquellos hechos que impidieron el paso militar o, como en el caso de la cabecera municipal de Pance, donde fue destruido el puesto de policía, y que desde entonces no ha sido reparado. Por el contrario, otros dos pobladores expresan que no es posible hablar de tomas cuando deja de existir la estación de policía, de ahí en adelante lo sucedido se nombra como enfrentamiento. Los relatos mencionan, tímidamente, las amenazas, hostigamientos y extorsiones que también sucedían en el lugar.

Cuando se le pregunta a Evangelina por los daños ocurridos durante las tomas, ella piensa primero en los muertos. Y es, precisamente, por la ausencia de muertos cercanos que ni ella ni Alba se sienten víctimas directas del conflicto armado, o que en sus narrativas no se reconoce que los hechos de violencia presentados en su corregimiento podrían corresponder con 7 de las 13 trece modalidades de victimización que se han hecho del conflicto: desplazamiento de población, despojo de tierras, secuestro, extorsión, homicidios, ataques y pérdidas de bienes civiles, y atentados contra bienes públicos ${ }^{15}$.

14. Ver: "La guerrilla atacó subestación Pance" (1995); "Guerrilla mata a dos hombres en Pance" (1996); "Un policía muerto y 4 heridos en La Vorágine" (1998); Domínguez (2011).

15. Pizarro (2015) habla sobre las trece modalidades. 
Gran parte de mi niñez la pasé encerrada porque no podía salir a jugar a la calle porque llegaba la guerrilla. Cuando por fin pude montar bicicleta, que hacía cosas de un niño de mi edad, tampoco las podía hacer, porque estaba el tema de que los guerrilleros se fueran a venir a tomar en cualquier momento ese puesto, y juraron toda la vida, que se iban a llevar el puesto de La Vorágine, pero por más que hicieron intentos no pudieron, le tiraron, que rocas, que bombas, pero ellos no pudieron (Alba, comunicación personal).

En octubre de 1991, las FARC realizaron un ataque en Pance, destruyendo la inspección de policía y la caseta comunal donde funcionaba la escuela. Este estuvo precedido por "atentados y asesinatos de personas pertenecientes a familias de pequeños propietarios de la región en cuyos predios tenían interés algunos narcotraficantes" (Domínguez, 2011: 128). Según Domínguez (2011), desde mediados de los noventa, hay un reconocimiento general de los pobladores sobre el control de las FARC en la zona, que se complementa, según versiones de estos, con "una especie de acuerdo no formal, en el cual la policía controlaba la delincuencia en la región hasta donde terminaba la carretera pavimentada en esa época; y la guerrilla se encargaba desde allí hasta la cordillera occidental" (130).

Evangelina y Alba recuerdan que otra de las tomas fue un domingo en horas de la tarde, en noviembre de 1998. Narran que el comandante del puesto de policía y dos agentes que lo acompañaban almorzaron en un estadero de la zona. Dicen que, como la policía sabía de la presencia guerrillera en el sector, para almorzar se turnaban de forma estratégica en diferentes establecimientos durante la semana. Ese día, una señora de la comunidad fue obligada a cerrar el parqueadero comunitario. La guerrilla ${ }^{16}$ sabía que el comandante y sus hombres almorzaban ese día en el estadero de Alba y los estaban esperando en el parqueadero, camuflados. El primero en salir del estadero fue uno de los agentes que acompañaba al comandante, y fue herido allí mismo. El otro agente se devolvió al escuchar los disparos, atravesó el negocio y huyó por el río. Pero el comandante fue a enfrentarlos y cayó en el parqueadero. Alcanzaron a llevarlo a la clínica de la policía, pero unos días después murió, al igual que el otro agente herido.

Para Alba y Evangelina, lo más difícil de esta toma, además de la muerte de los dos policías, a quienes conocían y atendían con frecuencia en el negocio, fue que amenazó la vida y la seguridad de quienes estaban en el negocio, porque se vivió en el día más concurrido de la semana y en un horario en el que todavía había clientes.

Coincidente con las versiones de Evangelina y Alba, el diario El Tiempo (Un policía muerto y 4 heridos en La Vorágine, 1998) reportaba, el 10 de noviembre, el

16. En sus relatos, los entrevistados no identifican con exactitud qué grupo guerrillero hizo las tomas, pero sí que en el sector hacían presencia tanto las FARC como el ELN. 
ataque cometido por varios hombres armados en el corregimiento de Pance, presuntamente de la guerrilla. En el hecho había sido asesinado un agente de policía de 37 años, vinculado a la institución desde hacía 15, y también fue herido un dragoneante de 36 años. El diario también afirmaba que esta era la primera vez en que se presentaban heridos civiles: se trataba de dos mujeres visitantes de 18 y 30 años, y una mujer residente de la zona, de 37 años. Todas ellas remitidas a hospitales de Cali, y una de ellas fue referida en las narraciones de Evangelina: "y una muchacha también fue herida porque, pues, aquí había gente y con el tiroteo se asustaron, empezaron a abrir la puerta y empezaron a salir a la calle, ahí salió una pelada herida y ella como que murió también".

En los relatos de Lucio sobre estos hechos abundan las descripciones generales, varios silencios, y dudas y prevenciones antes de hablar. Plantea, al igual que doña Evangelina, que el conflicto afectó profundamente la principal actividad económica del corregimiento: "porque cuando se sabe que aquí hay hostigamientos, que la violencia está en Pance, los turistas no vienen, y nosotros no vamos a ningún lado, nadie sale de la casa ni se asoma a la calle, todo se afecta".

Desde mediados de los noventa, se produjo un incremento de acciones e indicadores de violencia en la región, con muy altos niveles de impunidad ${ }^{17}$. En este tiempo, además, se produjo una serie de secuestros masivos en Cali que llevaron a pensar, a diferentes sectores, que "la guerra se vino del campo a la ciudad"18. Adicionalmente, en julio de 1999 hubo una expansión de los grupos paramilitares en el Valle del Cauca, que dio origen a la formación del Bloque Calima de las Autodefensas Unidas de Colombia, AUC. Su accionar incluiría unas 47 masacres en el Valle del Cauca, durante la primera década del siglo XXI, 14 de ellas ejecutadas solamente durante el año 2000 (Acosta, 2012).

Él todos los días se iba a mercar. Eran las nueve de la mañana y él se comunicó por radio y nos dijo: "métanse todos al sótano y enciérrense, porque no me dejan pasar de la Universidad San Buenaventura, porque ya la guerrilla se tomó La Vorágine” (Evangelina, comunicación personal).

Para varios pobladores, la toma más fuerte fue en 1991, cuando, como relata Alba:

Comenzaron a utilizar los cilindros bomba (...) y con tanta gente que estaba aquí uno no sabía cuándo una de esas vainas iba a explotar (...). Yo recuerdo que intentaron dañar

17. De acuerdo con Atehortúa (1998), en los años noventa la identificación del homicida no se lograba en un $80 \%$ de los casos.

18. Se trata de los secuestros de la iglesia de La María (3o de mayo de 1999), el Kilómetro 18 (17 de diciembre de 2000) y los diputados del Valle del Cauca (11 de abril de 2002). Ver: Barón (2016). 
el puesto de policía varias veces, también sufrimos cilindros bomba. En la última, yo estaba más grande, mi papá estaba vivo. Uno de los cilindros bomba fue puesto en el techo de la vecina allá abajo. También dispararon rockets que se quedaron en el río y no estallaron, pero se quedaron ahí cerquita. Nosotros estábamos acá, en el sótano, encerrados. La onda de choque hubiera podido destruir nuestra casa y otras de la vereda. El puesto de policía no lo dañaron por un milagro de Dios, porque hicieron de todo para volarlo, para dañarlo (Alba, comunicación personal).

En esta toma, los guerrilleros bajaron de la montaña por senderos difíciles de recorrer, con temperaturas muy frías y mucha neblina. De acuerdo con Evangelina, ellos tomaron el camino de Jamundí y Peón, Banqueo, después se metieron por detrás del club y entraron por el antes llamado Ecoparque de la Salud; ahí fueron vistos por habitantes del sector, cuando se subían a unos jeeps y camiones. Una vecina que los vio pasar llamó por radio a avisar para que se escondieran quienes vivían cerca a la estación de policía. "No se perdían porque ahí había baqueanos de acá. El hijo del carpintero, Jimmy, él se conocía todos esos senderos, junto a gente de la zona que también estaba metida en la guerrilla" (Habitante del sector, comunicación personal).

Al frente de la casa de un vecino vendían fritanga en unas vitrinas puestas sobre mesas de hierro, que fueron usadas por los guerrilleros para montar los cilindros bomba. En esa casa había una terraza en obra negra, y Alba cuenta que los guerrilleros se subieron allí a lanzar los cilindros a la estación de policía:

Toda la gente estaba superasustada, pero lo que más me impresionó era que yo nunca había visto el puente así. Pusieron esos cilindros bomba donde vivía Mayer, y ahí donde don Mariano porque cogían, los armaban ahí con unas mesas de los mismos negocios y los tiraban al puesto de policía. El puente estaba lleno de vainas de ametralladora, amarillito, amarillito lleno de vainas (Alba, comunicación personal).

Alba y Evangelina conocían al muchacho encargado de poner las cargas explosivas del grupo guerrillero que operaba en ese sector: era menudo y de baja estatura, parecía un niño. Este aspecto le ayudaba a pasar desapercibido por las requisas de los policías. Dentro de sus funciones estaba accionar las bombas de dinamita, por lo que estuvo relacionado con las cargas explosivas puestas en torres eléctricas del sector. Se sabe que él está en la cárcel.

Para Lucio, lo más insoportable eran las imágenes y sonidos de los cilindros que halaban los guerrilleros:

Sentimos cuando se arrastraban los cilindros aquí. ¿Usted sabe qué puede causarle a uno, con su propia familia en la casa, que tiren un cilindro de esos? ¿Qué debe sentir uno cuando ve que los cilindros los están arrastrando por la carretera contigua a su 
casa? Donde una vaina de esas explote, aquí nos matamos. Eso causa una tensión tremenda (Lucio, comunicación personal).

Alba escucha a su madre recordar que en esa toma los guerrilleros también tenían el objetivo de volar el puente para incomunicar al corregimiento de Pance con la ciudad:

Yo nunca había visto el puente así. Se veía llenito de vainas de ametralladora, se veía amarillito, como si tuviera un recubrimiento dorado encima del cemento, de tantas vainas de ametralladoras que se habían disparado durante la toma. Esa imagen se me grabó porque yo nunca había visto eso de esa manera (Evangelina, comunicación personal).

De acuerdo con Alba y Evangelina, en esta última toma los guerrilleros no lograron cumplir con su propósito porque "todo les falló". Fue un milagro que los cilindros no estallaran, uno quedó incrustado en el techo de la casa de una vecina, y dos de ellos cayeron en el río. "El río Pance no los dejó explotar", es la única explicación que encuentran.

Alba recuerda que el territorio cambió después de la llegada del Batallón de Alta Montaña, en el año 2003, aunque sabían que "aquí todavía seguía habiendo grupos guerrilleros y que ellos trataban de meterse en la Junta de Acción comunal, y pues nosotros tratábamos de no dejarnos permear de esa situación”. También recuerda que, por ese tiempo, capturaron a un hombre acusado de la participación en el secuestro de una niña de uno de los colegios de élite de Cali. Este secuestro fue registrado por la prensa local (Después de 197 días, liberan a niña, 2002). Y cuando "estaba haciendo mi práctica en un juzgado penal del circuito yo lo vi encadenado de manos y de pies. Y ese señor me reconoció y me dijo: ‘Hola, ¿cómo está?', y yo le dije: 'Buenas tardes', pero fue impresionante... ver una persona con la que vos hacías, con la que tu papá hacía trabajo comunitario" (Alba, comunicación personal).

Evangelina, Lucio y dos pobladores más concuerdan en atribuir al Batallón de Alta Montaña (Presidencia de la República, 2003) la reducción paulatina de los enfrentamientos entre grupos armados al margen de la ley, con la policía y el ejército. La presencia de este batallón hizo que estos grupos se refugiaran en lo alto de la cordillera.

\section{Cuidar el río y sus formas de vida y bienestar}

El río les facilitó a los actores de la violencia muchas cosas. Pero no directamente porque el río haya promovido ese tipo de violencia, sino porque ellos tomaban los recursos del río. Lo que promueve todo esto es la ausencia del Estado en los lugares donde hay necesidades básicas insatisfechas. Muchas personas del territorio que vivían 
del campo se pusieron a hacer cosas que no debían con esa gente, porque realmente no tenían oportunidades, eran visibles las carencias en educación y servicios de salud (Alba, comunicación personal).

Los efectos del conflicto armado vividos por la comunidad del corregimiento de Pance, durante las tomas guerrilleras, no se comparan en su dimensión a otros hechos del conflicto en el Valle del Cauca, como la Masacre de Trujillo, la del Naya o la llegada del Bloque Calima al departamento. De ahí que para algunas personas en Colombia sea invisible la llegada del conflicto a Pance, como lo expresa Alba cuando cuenta que en las conversaciones con allegados que habitaban la zona urbana de Cali se evidenciaba el no reconocimiento de lo acontecido en Pance durante el conflicto armado. Por ejemplo, Alba recuerda una conversación que sostuvo con su mejor amiga sobre el voto del plebiscito por la paz en Colombia:

Ella me decía: "Alba, pero si vos no viviste la violencia, vos no pusiste un muerto, vos no sos quién para decir que sí y que no a la paz". Yo le respondí: "No, yo no puse un muerto, eso es cierto. Pero yo sí vivíla violencia desde muy pequeña. Yo desde los dos años de edad escuché balas y bombas. No podía salir a jugar, no podía hacer muchas cosas que otros niños sí podían hacer, no podía vivir una vida como una persona normal” (Alba, comunicación personal).

Cuando se le pregunta a Alba sobre el sentido de recordar, ella argumenta:

Creo que recordar te ayuda a soltar, recordar te ayuda a avanzar, recordar te ayuda a no querer vivir la misma situación y a asumir una actitud distinta (...). Para todo ribereño, el río es la vida. Yo me considero una habitante ribereña. Todo lo que nosotros hacemos, vivimos y somos, gira en torno al río, es la vida (...).

Nosotros somos un corregimiento sobre la ribera del río. Mis papás son ribereños desde hace muchos años, mi abuela fue ribereña y todos hemos sido ribereños. Para los que seguimos aquí, a orillas del río, este es nuestro estilo de vida. Mi padre nunca pensó en dejar Pance por el conflicto, mi madre sí, pero yo no me podría imaginar por fuera de Pance, no me veo en Cali, me desespero. Cuando visito Cali, en el camino de regreso me siento diferente, feliz. Yo estoy acostumbrada a vivir en otro clima, a levantarme y observar el río, a cuidarlo, a hacer todo en torno al río (Alba, comunicación personal).

Para Lucio, el ejercicio de memoria es necesario porque "muchas personas no están enteradas del cómo, el cuándo y el por qué suceden ese tipo de cosas". Alba enfatiza en que la acción de recordar permite la no repetición de los hechos y el cambio en la actitud frente a la vida. Para ella, además, los colombianos estamos 
viviendo un momento crucial en la política, que se deriva de la firma de los acuerdos de paz con el grupo de las FARC en 2016. No obstante, considera que la paz significa el cese completo de actividades violentas por parte de grupos armados ilegales en todos los territorios del país. Pero este es aún un sueño que avizoran en un muy largo plazo. Así, Alba sostiene:

Lo que tengo claro es que lo último que quiero recibir para mí, para mis hijos, para mi mamá, para lo que me quede de existencia, es volver a vivir un conflicto. (...) me siento muy orgullosa de hacer este trabajo (dirigir el estadero), de tener mi proyecto agroecológico, de vivir en la forma en la que vivimos, porque es algo que disfruto (Alba, comunicación personal).

Alba enfatiza en que la acción de recordar abre caminos a la no repetición de los hechos y a cambios en las actitudes frente a la vida de las personas que vivieron el conflicto. Los participantes accedieron a un trabajo de memoria con el fin de esclarecer los hechos, pero no quieren que su territorio sea estigmatizado ni, mucho menos, que las violencias regresen.

Estamos en un proceso de construir territorio desde una cosmovisión armónica con el entorno, con la naturaleza, con los recursos ecosistémicos, que permita solucionar los conflictos sanitarios y manejar el turismo. A Pance viene mucha gente que necesita lugares de esparcimiento para no enloquecerse y no volverse más violenta. Estar en el río también contribuye a la salud mental. Si tú estás encerrado en la ciudad con calor, como en un gueto, y tienes la posibilidad de, por solo dos mil pesos, venir al corregimiento de Pance y tirarte a esa agua fría, relajante y deliciosa; acostarte sobre una piedra, mirar pajaritos, arbolitos, eso te relaja. Luego te devuelves como nuevo para Cali. Porque el río genera ese efecto de paz en las personas (Alba, comunicación personal).

Este proceso de construcción de territorio no solo aparece en los discursos de Alba, Lucio o Evangelina, sino que se acompaña de acciones llevadas a cabo por los habitantes de Pance que buscan que los visitantes del lugar puedan cuidar el ecosistema (ver Figura 2).

Alba, Lucio, Evangelina y el resto de habitantes del corregimiento saben que su bienestar económico depende de los turistas que visitan el corregimiento por su variedad de fauna y flora, pero se enfrentan con una paradoja: algunos turistas, e incluso personas del corregimiento sin sentido de pertenencia hacia el lugar, que no cuidan ni valoran los recursos naturales no renovables, como el río Pance, pueden ser "la perdición" para el turismo en el corregimiento. 
FIGURA 2 Manifiesto comunitario en Pance

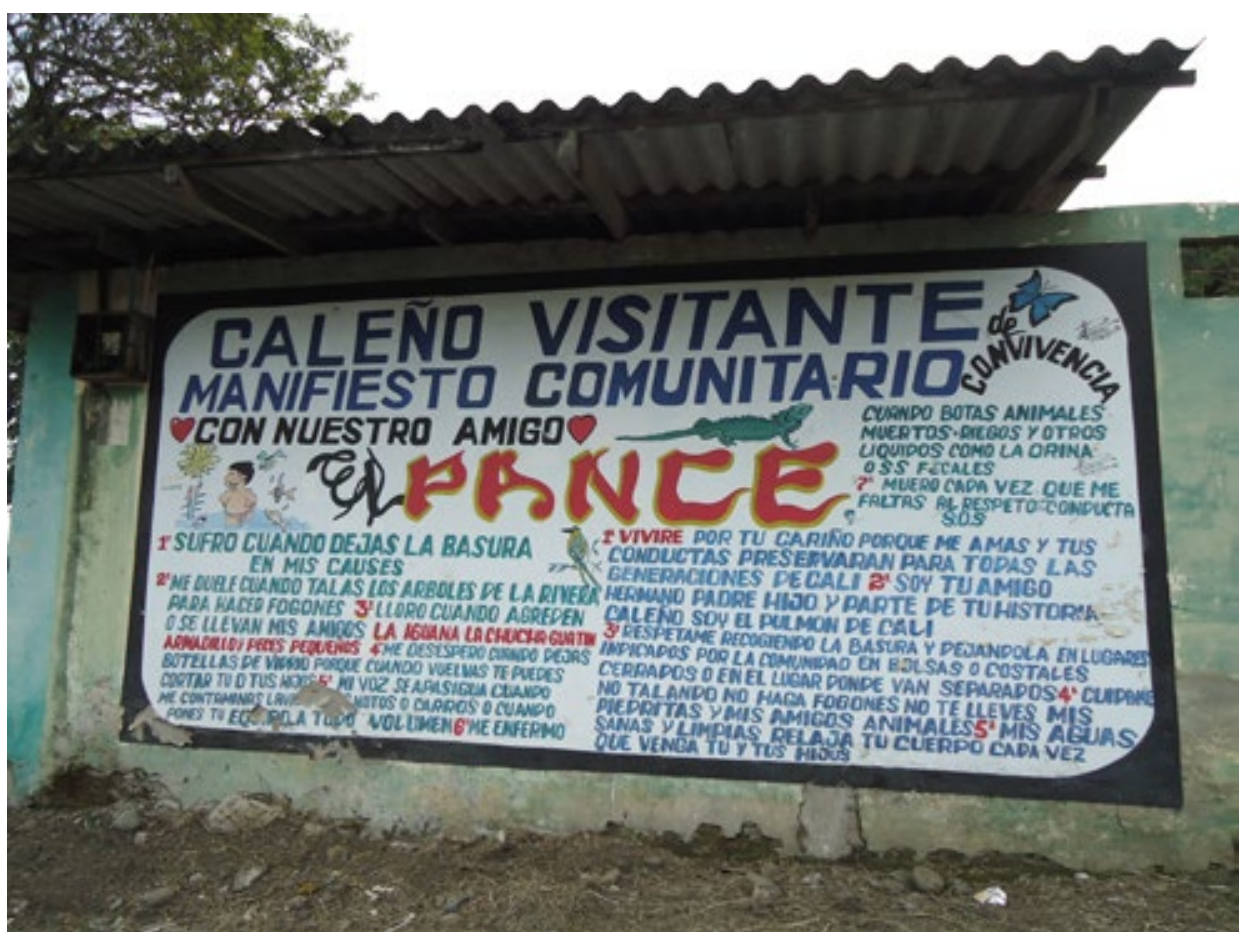

Fuente: fotografía propia, 2017

Por eso, Alba quiere a Pance libre de todo tipo de violencias relacionadas con la presencia de actores armados, y de las que se ejercen contra la naturaleza y atentan contra la costumbre del paseo de río. Para ella es impensable que el río no pierda la pureza de sus aguas y se convierta en otro río no visitado, como El Aguacatal, Meléndez, Lili, Cañaveralejo o Cali. Lucio solo quiere mencionar aquellos hechos que relacionan al río con la paz; él quiere concentrarse en el trabajo comunitario que promueve la preservación de los recursos naturales en beneficio de los habitantes y visitantes de Pance.

Para Evangelina y para muchos de la comunidad, el sancocho es la vida misma. De esta tradición han vivido y en ella han crecido las familias durante años. De ella ha podido construir sus sueños. Para Lucio y Alba el río es el responsable de que sus 
vidas sean como son: llenas de naturaleza, de arduos días de trabajo y momentos de armonía. Solo basta dar un vistazo al río para entender que sus esfuerzos comunitarios están en el lugar apropiado.

\section{Discusión y conclusiones}

Ningún hombre puede cruzar el mismo río dos veces, porque ni el hombre ni el agua serán los mismos.

Heráclito

Los relatos de los participantes, así como la información secundaria consultada en este trabajo, evidencian cómo la vida y las representaciones en Pance se han transformado desde los años setenta. Por ejemplo, ofrecen información sobre las migraciones de gente del campo en la región, producto tanto de las violencias partidistas como del crecimiento industrial y de las nociones de progreso de Cali y el Valle del Cauca, así como de las trayectorias del conflicto armado y sus actores, que inciden en el desplazamiento y reorganización de economías campesinas.

También dan cuenta de cambios de prácticas agrícolas y de carácter extractivo, hacia otras de conservación de los recursos naturales, principalmente de las fuentes de agua y del crecimiento del turismo, como las formas predominantes para asegurar la subsistencia de las comunidades que habitan este lugar. Además, evidencian la llegada de organizaciones guerrilleras a la zona, con los efectos que estos hechos han tenido en la vida cotidiana y en episodios de violencia con resonancia local y nacional, que corresponden con el escalamiento del conflicto político en la región y en el país.

$\mathrm{El}$ análisis de los ejercicios de recuerdo y de las narrativas que han resultado en este trabajo llevan a proponer que los usos de la memoria y el olvido, en este caso, tienden a favorecer las representaciones sobre las riquezas naturales y ecológicas de Pance, de la tranquilidad y paz de este lugar, y del valor de tradiciones populares como la del paseo de olla. Por lo anterior, esta parte final del texto se centrará en dos apartados: el primero, "Recordar para luchar por la conservación ecosistémica de Pance", permitirá exponer la funcionalidad de la rememoración para los participantes de la investigación, vinculada con la protección de su territorio y con sus trabajos cotidianos actuales en pro de la preservación de su espacio vital y de su sobrevivencia. El segundo apartado, "Olvidar para cuidar a Pance y al paseo de olla", posibilita reflexionar sobre las razones que llevan a los participantes a restar importancia a hechos relacionados con el conflicto armado experimentados en esta zona, y a relacionarlas con un fenómeno mayor como la banalización de las violencias en Colombia. 


\section{Recordar para luchar por la conservación ecosistémica de Pance}

Escuchar y darles voz a Evangelina, Alba y Lucio permite evidenciar la importancia del territorio en la vida de las personas, y la dificultad para abandonarlo cuando son obligadas a convivir con hechos violentos. En este punto, las problemáticas del conflicto armado-históricamente situadas a finales del siglo pasado en este territorio- ceden el protagonismo a conflictos y preocupaciones actuales de tipo ambiental. Pance es importante en tanto conserva la pureza de las aguas de su río, por sus riquezas vegetales y animales, y por el ambiente que provee a quienes lo visitan. Por ello, Alba, Evangelina y Lucio reconocen que, si la comunidad no se empodera de su territorio, su río puede verse afectado por la contaminación derivada de un turismo no consciente del cuidado de la naturaleza. Ellos hacen esfuerzos de liderazgo comunitario para trabajar a favor de la conservación del río y del ecosistema de Pance.

La memoria, entendida desde una perspectiva neuropsicológica, es el proceso mediante el cual adquirimos, guardamos y recuperamos la información. Sin esta capacidad sería imposible asumir una identidad personal o dotar de sentido nuestra vida (Carrillo-Mora, 2010). Si se entienden los ejercicios de memoria como procesos creativos y voluntarios inseparables de la identidad, que implican una selección de hechos vividos en el pasado que son reinterpretados, se ubica una fortaleza en las rememoraciones hechas con las personas. Hacer memoria da sentido a lo que somos y hacemos, brinda elementos de la historia propia para rememorar los motivos por los cuales seguimos vivos y luchando por la vida.

Hacer memoria, entendida como compuesta de memoria y olvido, les permite a Alba, Evangelina y Lucio contar sus vivencias del conflicto como algo que no pueden borrar, pero en sus relatos se ve una apuesta por preservar el recuerdo de Pance como un territorio de paz en la memoria de todos sus visitantes. Lo anterior les permite, a través de la narrativa, construir una identidad que recrea más fielmente lo que desean ser: empresarios, emprendedores, ribereños y, en todo caso, no víctimas.

Para Pierre Nora (2008), la memoria hace parte de la identidad. De acuerdo con los hechos vividos, enmarcamos lo que anhelamos o no queremos seguir siendo y viviendo. En la construcción de esa identidad, se van generando lugares de memorias que después se recopilan en la identidad. Parte de la identidad individual conforma a la identidad colectiva, por ello es necesario pensar que es posible vincular las futuras generaciones, que vivirán en un contexto heredado.

La identidad de Alba gira en torno a todo lo que ella ha construido a las orillas del río. Ella pertenece al corregimiento de Pance y no puede imaginar su vida por fuera de este espacio. Ni siquiera las experiencias del conflicto le hicieron pensar en la posibilidad de ir junto a su familia a otro lugar. Hoy, uno de sus trabajos más importantes como lideresa consiste en visitar los colegios de su vereda y hacer pe- 
dagogía alrededor de la importancia de conservar el ecosistema y el río Pance, con los niños y las niñas del sector.

De acuerdo con los participantes de los estudios, la parte alta del corregimiento -donde está ubicado el Parque Nacional Natural Farallones de Cali- se ha logrado conservar por la no intervención de entidades privadas, las cuales se mantuvieron alejadas por la presencia de actores armados ilegales. Caso contrario es el estado de la parte baja de la subcuenca, la cual está más cerca de la ciudad, y donde se presentan presiones antrópicas, las cuales han ido afectando al paisaje y los beneficios ecosistémicos, a raíz de la deforestación y sus consecuencias.

En esta línea, algunos medios de comunicación han planteado que después de la firma de los acuerdos de paz con las FARC se ha dado un incremento de la deforestación, por ejemplo, en el año 2017 se estima que se han perdido 220.000 hectáreas de bosque, equivalentes al tamaño de dos de las ciudades más importantes del país (Hernández, 2016; Rico, 2018; Semana Sostenible, 2018).

Derivado de las representaciones del medio ambiente en los ámbitos nacional y mundial, los pobladores en Pance ven que sus luchas sociales ahora van a involucrar otros actores políticos y económicos con los que ven grandes dificultades para llegar a acuerdos y seguir cuidando de esta fuente de agua, oxígeno y vida. Por ende, las memorias de los tres participantes no solo tratan de cuidar la imagen y la preservación del Pance, sino también las propias imágenes que tienen de sí mismos como parte del lugar, así como de la vida y el buen vivir que este representa.

\section{Olvidar para cuidar a Pance y al paseo de olla}

Durante los ejercicios de rememoración con Alba, Evangelina y Lucio, resultó importante que para ellos los relatos sobre el conflicto armado del país se centraban en los hechos más visibles, e incluso crueles, producto de las violencias del país y de la región, principalmente en aquellos que habían sido destacados por los medios masivos de comunicación y que se encontraban por fuera de su territorio. Al intentar abordar los hechos acontecidos en su corregimiento, se encontró que los participantes estaban buscando cuidar el territorio y a ellos como parte del mismo. Así, se evidencia en los relatos de Lucio que no desea que se conozcan los detalles de lo vivido en el corregimiento durante el conflicto armado, para que sus visitantes o potenciales visitantes se sientan tranquilos al visitar la subcuenca del río Pance.

En sus muy variados relatos, también buscaban restar importancia a lo sucedido en la zona, pues los hechos violentos no habían producido números significativos de muertos, heridos o retenidos, sino "solo" daños en los negocios y en sus alrededores. En los relatos de doña Evangelina, por ejemplo, incluir alguna cantidad de muertos en alguno de los episodios lo haría adquirir relevancia. En el relato de Alba, se recuerda 
cuando una de sus amigas le expresaba que ella no había vivido el conflicto en Pance, pues vivir el conflicto desde esta postura estaba relacionado con "poner muertos".

Pero los olvidos sobre el conflicto también se observan en textos académicos, informes de prensa o percepciones de gente no solo de Pance, sino también de Cali. La mayoría de escritos académicos no muestran las relaciones entre el territorio y el conflicto armado, y han centrado sus miradas en asuntos socioambientales, de territorialización y, más recientemente, sobre el turismo en el corregimiento.

Por ejemplo, Orjuela (2017) se enfoca en la descripción de los conflictos socioambientales presentes en el territorio. Ella muestra cómo en la transformación territorial de Pance se evidencian tensiones entre los seres humanos y la naturaleza, que pueden configurarse en conflictos ambientales. De acuerdo con la autora, en este territorio es posible ubicar conflictos hídricos ${ }^{19}$ por el acceso, gobernanza y concesiones de agua; conflictos relacionados con la extracción minera del lecho del río Pance; y conflictos derivados del cambio en el uso del suelo, como sucede con la extensión de la comuna 22 de Cali hacia Pance. El conflicto armado es mencionado por Orjuela (2017) como parte del contexto sociohistórico del corregimiento, al mencionar la llegada a Pance de "soldados oriundos del Cauca y Nariño que trataban de desertar de la guerra de los mil días en 1903" (67).

De manera similar, aun son pocos los estudios que abordan las violencias del conflicto armado en esta región (Barón, 2016; Pérez; Sánchez; Zúñiga, 2014; Robayo; Garcés, 2015). Incluso, como se pregunta Domínguez (2011:114), no se ha dado visibilidad a la importancia del agua y su relación con la guerra y los conflictos sociales en la región, que desde hace tres décadas han involucrado a instituciones estatales, élites, finqueros y hacendados, comunidades campesinas de pequeños propietarios y grupos armados ilegales, conformando diversas arenas de interrelación. Por el contrario, se privilegian las miradas sobre Pance como un lugar de bienestar, naturaleza y salud, tal como se refleja en un artículo de la prensa local que destaca su apertura turística y el encanto de sus aguas que hacen de este el principal balneario de la ciudad (El País, 2016).

Lo anterior sucede aunque los datos muestran que, entre 1986 y 2004, en el sector hicieron presencia regular diferentes grupos armados ilegales como las FARC, el ELN y los paramilitares. Adicionalmente, sus actos tuvieron diversas consecuencias, entre las que se cuentan los hostigamientos, las amenazas, los desplazamientos

19. Orjuela (2017) remite al lector al proyecto "Democratización de la gobernabilidad de los servicios de agua y saneamiento mediante innovaciones socio-técnicas" (Desafío) del Instituto Cinara, Universidad del Valle. Este proyecto caracteriza los conflictos ambientales presentes en Pance y enfatiza en que la vulnerabilidad de la comunidad del lugar se centra en el componente ambiental, porque su sustento se deriva del río Pance. 
forzados, el despojo y el abandono de tierras (Tribunal Superior del Distrito Judicial de Santiago de Cali, 2014).

Por otra parte, los informes del CNMH muestran que la mayoría de las víctimas del conflicto han tenido una doble y, en algunos casos, una triple vulneración (e.g. sus estudios sobre las masacres de Trujillo, de El Salado o de Mapiripán), así como dificultades en sus condiciones económicas y violaciones a los derechos humanos, al ser afectadas directamente por el conflicto. En la Ley 1448, para la atención y reparación integral de víctimas (Congreso de la República de Colombia, 2011), y en los Acuerdos de paz (Gobierno Nacional de Colombia, 2016) el enfoque central está en las víctimas, dado que en su mayoría son personas que padecen de esta doble vulneración. Incluso, por mandato legal, el CNMH ha privilegiado las memorias de las víctimas. Este tipo de consideraciones ponen en juego las definiciones mismas sobre las víctimas y el valor de sus testimonios. Ambos criterios tienden a centrarse, en muchos casos, en los números y cualidades de los afectados letales del conflicto, por encima de otros asuntos como las complejas condiciones humanas de quienes resultan involucrados e impactados por las violencias de los conflictos, como bien retrata Levi (2003), en su libro Si esto es un hombre, cuando muestra, de manera profunda, los papeles, posiciones e interacciones que se produjeron entre alemanes y judíos en los que él denomina centros de destrucción, que van más allá de las distinciones dicotómicas entre perpetradores y víctimas.

Es claro que la estigmatización de los territorios causa daños y genera privaciones en la población, de ahí que los olvidos mismos jueguen un papel fundamental para construir un espacio atractivo para el turismo. Sin desconocer la importancia social e histórica de estos hechos, cabe preguntarse si este fenómeno ha contribuido a una cierta banalización de otras violencias, tal y como ha sucedido con Pance, una comunidad que sufrió otro tipo de afectaciones, y que incluso sus mismos pobladores no consideran tan fuertes como para apartarles un espacio en la historia del conflicto armado colombiano. Se trata de violencias cotidianas que producen miedo, terror, aislamiento y destrucción de las relaciones, las confianzas y las acciones colectivas, y que vale la pena destacar.

El término de banalización fue acuñado por Arendt (1999) para describir el comportamiento de algunos individuos que, habiendo participado de los actos atroces de la Alemania nazi, habían actuado sin reflexionar sobre los efectos de sus actos, guiados por las órdenes burocráticas. En este caso, el término banalización se articula a prácticas culturales de normalización de las violencias, las barbaries y el terror. Para López (2017), en esta banalización -entendida como ejercicio de naturalización e incluso de justificación de acciones de violencia de agentes que afectan el concepto 
de persona- no solo tienen responsabilidad los medios, sino los mismos ejercicios de memoria, al poner a circular versiones hegemónicas de lo acaecido.

De acuerdo con Pécaut (1997), cuando se han producido escalamientos de las violencias y del terror en Colombia, también se han generado fenómenos de banalización de los mismos. Según el autor, algunos de estos fenómenos han estado relacionados con las percepciones sobre ciertas prácticas y proyectos económicos, que hacen ver las violencias y el terror como obstáculos o como alteraciones menores frente a ciertas actividades económicas de carácter legal e ilegal, y que llevan a naturalizar prácticas como los asesinatos, los secuestros o las extorsiones.

Lo anterior lleva a considerar cómo el desarrollo e imposición de proyectos y perspectivas económicas, en zonas como Cali y el Valle del Cauca, aparecen relacionados con la invisibilidad y olvido de formas de violencia y terror, lo que se puede observar en trabajos como el de Betancourth (2005), cuando muestra cómo las violencias han sido estrategias de control social que han posibilitado configurar las expresiones de construcción-deconstrucción de ciudadanía originadas en poderes locales difusos, o las omisiones frente a las mal llamadas "limpiezas sociales"; así como el escalamiento de la criminalidad e inserción política y cultural del narcotráfico, que se observan en los trabajos de Guzmán et al. (2018), y Camacho y Guzmán (1987); además de los olvidos y fronteras grises sobre la llegada y fortalecimiento del paramilitarismo en esta región, y el ejercicio de las masacres como una de sus principales herramientas de orden sociopolítico (Barón, 2016). Autores como Pécaut y Betancourth muestran que lo anterior, también, ha tenido profundos efectos en la construcción de identidades colectivas, y en la formación y legitimación de órdenes sociales y de formas precarias y diferenciales de ausencia-presencia del Estado-nación en los territorios (Gutiérrez, 2015).

De acuerdo con Calveiro (2012), en el acto de construir memoria social hay una funcionalidad política, dado que la memoria se compone de múltiples versiones que no se legitiman por su carácter de "verdad", sino por su credibilidad social. Las muertes, los desplazamientos y las diferentes violaciones a los derechos humanos, como consecuencia del conflicto armado colombiano, son hechos que pueden verificarse, pero la construcción social que de ello derive, los significados que se recuerden (y los que se olviden) están en disputa. De la misma manera, Todorov (2000) muestra que la acción de recordar es, necesariamente, un proceso de selección sobre qué merece ser recordado. Por lo tanto, el acto de olvidar también hace parte del acto de hacer memoria. Olvidar que Pance también fue afectado por el conflicto armado colombiano puede ser útil en tanto el estigma de la violencia desaparece, y el olvido le da paso a la prosperidad de los negocios dedicados al turismo del corregimiento y al bienestar del mismo. 
Es probable que los tiempos y organización de las investigaciones que soportan este ejercicio, así como la aplicación de las estrategias y herramientas metodológicas, hayan tenido incidencia en los asuntos y órdenes que predominaron en los relatos de los participantes, pues, como se ha mostrado, sus trabajos de memoria, aunque regresaban a los hechos del conflicto, muy pronto se devolvían a resaltar el presente y futuro de esta zona privilegiada por sus ecosistemas, por su paz y tranquilidad, así como los procesos organizativos que están tratando de conservarla y protegerla (a pesar de las muy diferentes concepciones que hay sobre estos términos). Sus memorias y narrativas tratan de cuidar su subsistencia y bienestar, los cuales todavía siguen ligados a la tradición del paseo, el río y el sancocho de leña.

Futuras investigaciones deberán profundizar en los silencios, los olvidos y las inconsistencias en las versiones sobre lo sucedido en la zona, que ofrecen pistas sobre las implicaciones que tienen los ejercicios de memoria en medio de la continuidad de los conflictos sociales en este territorio con tantos recursos y riquezas. También es importante considerar las incidencias que producen las violencias que no han cesado después del acuerdo de paz con las FARC en esta y otras regiones del país, en donde todavía se perciben los rastros del terror y las incertidumbres que producen las guerras.

Además, los fenómenos de banalización y normalización de las violencias deben ser trabajados de manera más profunda, así como los valores que se atribuyen a los diferentes tipos de víctimas y afectados por el conflicto armado, y a las prácticas y procesos de victimización. En este sentido, será necesario trabajar sobre el valor, calidad y veracidad de los testimonios de quienes han vivido las violencias de maneras tan diversas, y de las hegemonías de las memorias que también se pueden configurar desde sectores y espacios considerados tradicionalmente como vulnerados, excluidos o marginados.

\section{Referencias}

Acosta, Catalina (2012). Anatomía del conflicto armado en el Valle del Cauca durante la primera década del siglo XXI. Revista Científica Guillermo de Ockham, 10(1), 67-82.

Allier, Eugenia; Crezel, Emilio (eds.) (2015). Las luchas por la memoria en América Latina. Historia reciente y memoria política. México: UNAM/Instituto de Investigaciones Sociales.

Arendt, Hannah (1999). Eichmann en Jerusalén. Un estudio sobre la banalidad del mal. Barcelona: Lumen. 
Atehortúa, Adolfo (1998). Construir paz, elementos de diagnóstico para el diseño de un modelo de aproximación histórica al contexto general de las violencias en Cali. Santiago de Cali: Universidad del Valle/Instituto de Altos Estudios Jurídicos y Relaciones Internacionales.

Barbuto, Valeria (2012). Los sitios de la memoria en la agenda de la democracia. Red Universitaria sobre Derechos Humanos y Democratización para América Latina, 3, 125-137.

Barón, Luis (2016). “Se nos salió de las manos...”. Memorias de empresarios sobre el conflicto armado en el Valle del Cauca. Tabula Rasa, 24, 263-301.

Barón, Luis (2018). Introducción: Épica, mesianismo y normalización. En Empresarios, guerras y memorias. Testimonios desde el Pacífico Colombiano (pp. 21-43), editado por Luis Barón; María Wills. Cali: Universidad Icesi/CNMH.

Betancourt, Darío (2005). Organizaciones de tipo mafioso en el Valle del Cauca 1975-1995, en C. Castro (comp.), En torno a la violencia en Colombia. Una propuesta interdisciplinaria. Cali: Universidad del Valle.

Bickford, Louis; Brett, Sebastián; Ríos, Marcela; Ševčenko, Liz (2007). Memorializacióny Democracia. Políticas de Estadoy Acción Civil. Santiago de Chile: Flacso Chile/ICTJ/International Coalition of Sites of Conscience.

Bourdieu, Pierre (1989). La ilusión biográfica. Historia y fuente oral, 2, 27-33.

Bruner, Jerome (2002). La fábrica de hacer historias. Buenos Aires: FCE.

Buscan la declaratoria de todo Pance, como una zona de reserva natural (12 de noviembre de 2017). El Tiempo. Recuperado de https://www.eltiempo.com/colombia/cali/buscan-la-declaratoria-de-todo-pance-como-una-zona-de-reserva-natural-150246

Bustos, Guillermo (2010). La irrupción del testimonio en América Latina: intersecciones entre historia y memoria. Presentación del dossier "Memoria, historia y testimonio en América Latina”. Historia Crítica, 40, 10-19.

Calveiro, Pilar (2012). Apuntes sobre la tensión entre violencia y ética en la construcción de las memorias políticas. En Topografias conflictivas. Memorias, espacios y ciudad en disputa (pp. 21-30), editado por Valeria Durán; Anne Huffschmid. Buenos Aires: Nueva Trilce.

Camacho, Álvaro; Guzmán, Álvaro (1987). Indagaciones sobre la naturaleza social de la violencia urbana. Santiago de Cali: Universidad del Valle/Colciencias.

Carrillo-Mora, Paul (2010). Sistemas de memoria: reseña histórica, clasificación y conceptos actuales. Primera parte: Historia, taxonomía de la memoria, sistemas de memoria de largo plazo: la memoria semántica. Salud Mental, 33(1), 85-93.

Concejo de Santiago de Cali (2014). Acuerdo N. ${ }^{\circ} 0373$ de 2014. Por medio del cual se adopta la revisión ordinaria de contenido de largo plazo del Plan de Ordenamiento Territorial del mu- 
nicipio de Santiago de Cali. Recuperado de http://idesc.cali.gov.co/download/pot_2014/ norma_equipamientos.pdf

Congreso de la República de Colombia (10 de junio de 2011). Ley 1448 de 2011. Por la cual se dictan medidas de atención, asistencia y reparación integral a las víctimas del conflicto armado interno y se dictan otras disposiciones. Recuperado de http://wp.presidencia.gov.co/sitios/ normativa/leyes/Documents/Juridica/LEY\%201448\%20DE\%202011.pdf

Departamento Administrativo de Gestión del Medio Ambiente (2012). Informe de caracterización de aguas e indice de calidad de agua de los ríos Aguacatal, Cali, Cañaveralejo, Lili, Meléndezy Pance. Santiago de Cali: DAGMA.

Después de 197 días, liberan a niña (5 de abril de 2002). El Tiempo. Recuperado de https:// www.eltiempo.com/archivo/documento/MAM-1319417

Domínguez, José (2011). Las FARC-EP: de la guerra de guerrillas al control territorial (Tesis de maestría). Universidad del Valle, Facultad de Ciencias Sociales y Económicas, Departamento de Ciencias Sociales, Maestría en Sociología, Cali.

Echandía, Camilo (2013). Auge y declive del Ejército de Liberación Nacional (ELN): Análisis de la evolución militar y territorial de cara a la negociación. Bogotá: Fundación Ideas para la Paz.

El río Pance, amenazado por los malos turistas (9 de febrero de 2016). El País. Recuperado de http://www.elpais.com.co/cali/el-rio-pance-amenazado-por-los-malos-turistas.html

Escobar, Arturo (1997). La invención del Tercer Mundo. Construcción y deconstrucción del desarrollo. Caracas: Fundación Editorial El Perro y La Rana.

Fabri, Silvana (2013). Lugares de memoria y marcación territorial: sobre la recuperación de los centros clandestinos de detención en argentina y los lugares de memoria en España. Cuadernos de Geografia, 22(1), 93-108.

Garzón, Edward (2019). Valoración patrimonial del Parque-Monumento, Trujillo, Colombia: Memorial democrático al servicio de una comunidad de memoria. Revista CS, 28, 87-124. https://doi.org/10.18046/recs.i28.3267

Giraldo, Martha; Gómez, Jaime; Cadavid, Beatriz; González, Marcela (2011). Estudios sobre memoria colectiva del conflicto. Colombia, 2000-2010. Revista Interamericana de Bibliotecología, 34(3), 339-341.

Gobierno Nacional de Colombia (2016). Acuerdo final para la terminación del conflicto y la construcción de una paz estable y duradera. Bogotá: Gobierno Nacional de Colombia.

Grupo de Memoria Histórica. (2013). ¡Basta ya! Colombia: memorias de guerra y dignidad. Centro Nacional de Memoria Histórica. 
Guerrilla mata a dos hombres en Pance (19 de noviembre de 1996). El Tiempo. Recuperado de https://www.eltiempo.com/archivo/documento/MAM-599690

Gutiérrez, Francisco (2015). ¿Una historia simple? En Contribución al entendimiento del conflicto armado en Colombia (pp. 498-540), editado por Comisión Histórica del Conflicto y sus Víctimas. Recuperado de http://www.altocomisionadoparalapaz.gov.co/mesadeconversaciones/PDF/Informe\%2OComisi_n\%2OHist_rica\%2odel\%2oConflicto\%2Oy\%2O sus\%2OV_ctimas.\%2oLa\%2OHabana\%2C\%2OFebrero\%2ode\%2O2O15.pdf

Guzmán, Álvaro; Rodríguez, Alba; Muñoz, Nathalia (2018). Cali y la violencia paramafiosa. En Violencia en cinco ciudades colombianas a finales del siglo XX y a principios del siglo XXI (pp. 625-805), editado por Álvaro Guzmán. Cali: Universidad Autónoma de Occidente.

Hernández, Pablo (2o de diciembre de 2016). Los retos para la conservación luego del Acuerdo de Paz. Semana Sostenible. Recuperado de https://sostenibilidad.semana.com/medio-ambiente/articulo/los-retos-para-la-conservacion-luego-del-acuerdo-de-paz/36713

Huyssen, Andreas (2002). En busca del futuro perdido. Cultura y memoria en tiempos de globalización. México: FCE.

Kirwan, Brock; Ashby, Stefania; Nash, Michelle. (2014). Remembering and Imagining Differentially Engage the Hippocampus: A Multivariate FMRI Investigation. Cognitive Neuroscience, 5(3-4), 177-185. http://dx.doi.org/10.1080/17588928.2014.933203

La guerrilla atacó subestación Pance (5 de julio de 1995). El Tiempo. Recuperado de https:// www.eltiempo.com/archivo/documento/MAM-359500

Lambek, Michael; Antze, Paul (1996). Tense Past: Cultural Essays in Trauma and Memory. American Ethnologist, 25(3), 505-506.

Levi, Primo (2003). Si esto es un hombre (6. ${ }^{\mathrm{a}}$ ed.). Barcelona: El Aleph.

López, Dayán (2017). De la naturalización de la violencia a la banalidad del mal. Ratio Juris, 12(24), 111-126.

Luna, Mario (2006). El M-19 en el contexto de las guerrillas en Colombia. Sociedad y Economía, 10, 157-188.

Mesa ambiental corregimiento de Pance (2016). Estrategia de manejo socioambiental de la zona mediay baja de la subcuenca del río Pance. Recuperado de http://www.panceambiental.org/ estrategia-de-manejo-ambiental/

Nastase, Vivi; Koeszegi, Sabine; Szpakowicz, Stan (2007). Content Analysis Through the Machine Learning Mill. Group Decision and Negotiation, 16(4), 335-346.

Nietzsche, Friedrich Wilhelm (2006). Segunda consideración intempestiva: Sobre la utilidady los inconvenientes de la historia para la vida. Buenos Aires: Libros del Zorzal. 
Nora, Pierre (2008). Pierre Nora en Les lieux de mémoire. Montevideo: Trilce.

Orjuela, Viviana (2017). Relación ser humano-naturaleza en la comprensión de los docentes en formación inicial (Tesis de pregrado). Universidad del Valle, Instituto de Educación y Pedagogía, Área de Ciencias Naturales, Programa de Licenciatura básica con énfasis en ciencias naturales y educación ambiental, Cali.

Parques Nacionales Naturales de Colombia (2018). Parque Nacional Natural Farallones de Cali. Recuperado de http://www.parquesnacionales.gov.co/portal/es/ecoturismo/region-pacifico/parque-nacional-natural-farallones-de-cali/

Pécaut, Daniel (1997). De la violencia banalizada al terror: el caso colombiano. Controversia, $171,9-31$.

Pérez, Mario; Sánchez, Luis; Zúñiga, María (2014). Conflicto ambiental en el río Pance: entre diversos usos y usuarios del agua. Santiago de Cali: Universidad del Valle.

Pérez, Natalia (2017). Desarrollo rural y movilización social en la zona rural de la Subcuenca del Río Pance (Cali, Colombia). Revista CS, 21, 69-96. https://doi.org/10.18046/recs.i21.2273

Pizano, Camila; García, Hernando (2014). El bosque seco tropical en Colombia. Bogotá: Instituto de Investigación de Recursos Biológicos.

Pizarro, Eduardo (2015). Una lectura múltiple y pluralista de la historia. En Contribución al entendimiento del conflicto armado en Colombia (pp.5-98), editado por Comisión Histórica del Conflicto y sus Víctimas. Recuperado de http://www.altocomisionadoparalapaz.gov. co/mesadeconversaciones/PDF/Informe\%20Comisi_n\%2oHist_rica\%2Odel\%2OConflicto\%2Oy\%2Osus\%2oV_ctimas.\%2OLa\%2OHabana\%2C\%2OFebrero\%2Ode\%2O2O15.pdf

Presidencia de la República (5 de mayo de 2003). Gobierno activó batallón de alta montaña. Recuperado de http://historico.presidencia.gov.co/prensa_new/sne/2003/mayo/05/01052003.htm

Rico, Guillermo (2018). La selva en Colombia después del conflicto con las FARC. Mongabay. Recuperadodehttps://es.mongabay.com/2018/05/selva-colombia-despues-conflicto-farc/

Ricoeur, Paul (2004). Memory, History, Forgetting. Chicago: University of Chicago Press.

Rieff, David (2012). Contra la memoria. Madrid: Debate.

Robayo, Lina; Garcés, Wilson (2015). Construyendo territorios, construyendo geografías. Una mirada a la construcción de territorio en el corregimiento de Pance, Cali-Colombia. Entorno Geográfico, 11, 46-67.

Salazar, Andrés (26 de enero de 2018). Cali le abre las puertas al turismo de aves. Portafolio. Recuperado de http://www.portafolio.co/economia/cali-le-abre-las-puertas-al-turismode-aves- 513658 
Semana Sostenible (26 de junio de 2018). La paradoja de la paz: cuatro historias de destrucción ambiental tras el acuerdo con las Farc. Recuperado de https://sostenibilidad.semana.com/ medio-ambiente/articulo/deforestacion-en-colombia-despues-del-acuerdo-de-paz-conlas-farc $/ 41088$

Spradley, James (1979). The Ethnographic Interview. New York: Holt, Rinehart and Winston.

Stoller, Paul (2007). Ethnography/memoir/imagination/story. Anthropology and Humanism, 32(2), 178-191.

Todorov, Tzvetan (200o). Los abusos de la memoria. Barcelona: Paidós.

Tribunal Superior del Distrito Judicial de Santiago de Cali (9 de abril de 2014). Solicitud de Restitución y Formalización de Tierras de Rosa Elena Caicedo. Recuperado de https://www. restituciondetierras.gov.co/documents/10184/513351/760013121001-2012-00o88-o1-Santiago-de-Cali-9-de-Abril-2014.pdf/dcee4756-6263-42ef-bc3e-d46477775962?version=1.o

Un policía muerto y 4 heridos en La Vorágine (10 de noviembre de 1998). El Tiempo. Recuperado de https://www.eltiempo.com/archivo/documento/MAM-848850

Varela, Rodrigo; Bedoya, Olga (2006). Modelo conceptual de desarrollo empresarial basado en competencias. Estudios Gerenciales, 22(100), 21-47.

Vázquez, Edgar (2001). Historia de Cali en el siglo 20: sociedad, economía, cultura y espacio. Santiago de Cali: Universidad del Valle. 